office addresses in each State. This is followed by a list of Societies, Agricultural Colleges and Experiment Stations ; an account of the Entomological organizations at Philadelphia, and a list of Entomological publications. Every one who wishes to exchange his duplicates for specimens from distant localities should obtain a copy of this Directory. It can be obtained from E. T. Cresson, Box 248 , Philadelphia, Pa. (Price $5 \circ$ cents.)

Types of LePIDOPTERA.-Dr. Herman Strecker has now published the third part of the supplement to his "Lepidoptera, Rhopaloceres and Heteroceres, indigenous and exotic." It contains a list of all the types of species that are contained in his extensive collection, with bibliographical and geographical references. No less than 425 species and varieties are included in the list, an immense number for a private collection, and descriptions are given of a number of new species. It is a matter of great importance to students to know where the types of described species may be seen; Dr. Strecker has therefore done a good work in publishing this list. In an interesting preface he gives some account of the principal sources from which he has built up his remarkable collection during the last fifty years and the difficulties under which he laboured in early days. These supplements may be obtained from the author, P. O. Box $3^{\mathrm{r}}$, Reading, Penna. (Price 25 cents each.)

\title{
MONTREAL BRANCH OF THE ENTOMOLOGICAL SOCIETY OF ONTARIO.
}

The regular monthly meeting of the Montreal Branch of the Entomological Society of Ontario was held on Tuesday evening, at the residence of the President, Mr. A. F. Winn, $5^{8}$ Bruce Avenue, Westmount. The chair was occupied by the President, and there was a good attendance of members. The Very Rev. Dean Carmichael and Mr. C. P. Newman were elected members. Mr. Henry H. Lyman, ex-President, in a brief speech, presented Mr. Winn, on behalf of the members, with a handsome mantel clock, with a suitably-engraved piate, as a wedding present, it being the first time in the history of the Branch that a President had been married during his occupancy of the chair.

Mr. Winn, who was taken by surprise, replied on behalf of himself and Mrs. Winn, thanking the members heartily for the present, which he valued very highly. Mr. Lyman then read a paper on Fall Web-worm Moths and allied species.

ERratum.-On page ioo, sixth line from top, the word "six" has accidentally been omitied before "pairs under metatarsi I."

Mailed April 2nd, Igoo. 